\title{
PÄÄKIRJOITUS
}

SUVI-MARIA SAARELAINEN

\section{Pitkittynyt pandemia haastaa pohtimaan koronaoppeja ja tulevaisuutta}

Tähes kahden vuoden ajan koronaviruspandemia (COVID-19) on ollut _osa suomalaisten arkea. Tämä Diakonian tutkimuksen 2/2021 numerosta muotoutui muhkea koronatutkimuspainotteinen numero, joka tarkastelee sekä artikkeleiden että kirjoitusten myötä koronan moninaisia vaikutuksia diakonian ja kirkon työn piirissä. Monessa seurakunnassa kysytäänkin nyt: Mitä olemme pandemian ajasta oppineet? Mitä meidän tulisi tulevaisuudessa huomioida? Seurakuntien työn kannalta vaikuttaa siltä, että vaikka pandemian virustartunnat kääntyisivätkin laskuun, koronan jäljet seuraavat meitä vielä vuosien päähän. Ennakoitavissa on, että diakonisen tuen ja keskusteluavun tarve jatkuu vielä pitkälle tulevaisuuteen.

Aikakauskirjan artikkelit ja kirjoitukset tuovat vahvasti esille kohdatuksi tulemisen tärkeyden, moninaisen tuen tarpeen sekä aineellisen hädän, jota korona on osin pahentanut. Samalla esiin tulee myös ihmismielen vahvuus: elämän muutoksissa ihmisillä on halu kurottautua kohti merkityksellistä elämää. Tästä huolimatta lehdistö toi luettavaksemme jo ensimmäisen korona-aallon jälkeen, kuinka auttavat puhelimet tukkiutuivat ja tarve keskusteluavulle oli suuri. Uutisaiheiksi nousivat muun muassa nuorison pahoinvointi sekä opiskelijoiden mielenterveyden kysymykset. Myös syksyllä 2021 keräämämme elämän merkityksellisyyttä ja koronastressiä mittaava aineisto antaa alusta- 
vasti osviittaa siitä, että koronastressi on iskenyt ennen kaikkea alle 30-vuotiaisiin. Työttömyys, tulevaisuuden epävarmuus, sosiaalinen eristyneisyys sekä epävarma tulevaisuus ovat jättäneet jälkensä moniin, ikään katsomatta.

Pandemian helpottaessa monen tekisi luonnollisesti mieli palata vanhaan, olla kuten ennen. Tosiasia kuitenkin on, että pandemia on muuttanut meistä monia. Miten suunnitella kohtaamisia ja tapahtumien tarjontaa siten, että ne saavuttavat ihmiset monipuolisesti? Miten rakentaa myös ne ihmiset tavoittavaa toimintaa, jotka pandemian myötä löysivät tiensä striimin tai etätapahtumien pariin? Miten kutsua niitä, jotka kokivat tulleensa petetyksi kirkon ovien sulkeuduttua ja oman rakkaan yhteisön jouduttua tauolle?

Pandemian myötä vapaaehtoistoiminta katosi monin paikoin tyystin kokonaan: seurakuntien arvokas aarre laitettiin pakkolomalle, sillä pandemian kestoa oli mahdoton ennakoida. Monessa seurakunnassa on todettu, että nyt on aika kutsua vapaaehtoiset takaisin. Sen sijaan, että heitä kutsuttaisiin tekemään vanhaa tuttua vapaaehtoistehtävää, mitä tapahtuisi, jos heitä kutsuisikin mukaan kysymyksellä:"Mitä juuri sinä haluaisit tehdä omassa seurakunnassasi?” Toki seurakunnat kaipaavat ihmisiä mukaan myös perinteiseen vapaaehtoistyöhön, mutta kenties tarve on nyt myös uudenlaisille avauksille.

Tulevaisuuteen liittyy joukko isoja kysymyksiä, joihin ei ole helppoja vastauksia. Kysymyksiä, jotka vaativat avointa ja innovatiivista keskustelua, jotta syntyy myös uudenlaisia ratkaisuja, erilaista toimintaa tutun ja turvallisen rinnalle.

Seurakuntien työntekijöiden näkökulmasta olennaista on kuitenkin myös pysähtyä ja huomata, että elämme jälleen muutoksen aikaa. Siirtyminen hybridiin - mutta myös aivan tavalliseen, vanhaan normaaliin - on jälleen suuri muutos. Tällaiset siirtymät aiheuttavat aina stressiä ja kuormitusta. Jotta työntekijät voivat olla uuden toiminnan kehittäjinä ja tutun jälleenrakentajina, on olennaista kiinnittää huomiota siihen, että työntekijöiden voimavarat ovat riittävät. Vain hyvin jaksava työntekijä voi olla rinnalla kulkija ja elämän isojen kysymysten tasapainoinen keskustelukumppani. Myös työyhteisöissä on hyvä pysähtyä kysymään: Mitä kuuluu? Miten sinä voit tänään? 